\title{
Evaluation of the Effects of "High-Flow Nasal Cannula Oxygenation" Therapy on Vital Signs in Infants Diagnosed as Severe Acute Bronchiolitis Who Are Unresponsive to Conventional Therapy
}

Mücahit Koçoğlu $\odot$ Ali Güngör $\odot$ Başak Yalçın Burhan $\odot$ Cüneyt Karagöl $\odot$ Alkım Öden Akman $\odot$

\author{
Konvansiyonel Tedaviye Cevapsız Ağır Akut \\ Bronşiyolitli infantlarda "Yüksek Akımlı Nazal \\ Oksijen" Tedavisinin Vital Bulgular Üzerine Etkisi
}

\begin{abstract}
Objective: High-flow nasal cannula oxygenation (HFNC) therapy is reported to provide a significant improvement in vital findings in pediatric patients who develop respiratory distress during follow- up of acute bronchiolitis. In our study, we aimed to evaluate the effects of HFNC therapy on vital findings in infants diagnosed with severe acute bronchiolitis and also, we compared the mean duration and the number of hospitalizations of these patients in the intensive care unit with the period where HFNC was not available in our center.

Method: This observational, single center study included patients (1-24 months) diagnosed with severe acute bronchiolitis who were administered HFNC therapy $(1-2 \mathrm{~L} / \mathrm{kg} / \mathrm{min}$ with F\&P Airvo 2TM optiflow device) between October 2017 and March 2018. Duration of hospitalization, respiratory and heart rate, blood pressure, and saturation of oxygen change values at 1st, 6th, 12th, and 24th hours of HFNC therapy were evaluated.

Results: $A$ total of 41 patients was included in the study, $66 \%(n=27)$ were boys, the mean age was $7.5 \pm 5.6$ months, and the mean body weight was $7.5 \pm 2.2$ kilograms. Of all patients, 32 (78\%) were followed up in the ward, and $9(22 \%)$ were transferred to pediatric intensive care unit. Heart and respiratory rates were significantly decreased and saturation of oxygen was significantly increased at $1^{\text {st }}, 6^{\text {th }}, 12^{\text {th }}$, and $24^{\text {th }}$ hours. No significant difference was found in the duration of hospitalization compared to the period where HFNC was not available.

Conclusion: In our study, HFNC therapy significantly decreased respiratory and heart rate, and significantly improved $\mathrm{SpO}_{2}$. Our data about efficacy of HFNC therapy should be evaluated with multicenter studies.
\end{abstract}

Keywords: Acute bronchiolitis, high-flow nasal cannula oxygenation, respiratory distress, pediatric intensive care

öz

Amaç: Yüksek akımlı nasal oksijen (YANKO) tedavisinin, akut bronşiolit izleminde respiratuar distres geliştiren çocuk hastalarda vital bulguları belirgin düzelttiği belirtilmektedir. Çalıșmamızda ağır akut bronşiolit tanılı infantlarda YANKO tedavisinin vital bulgulara etkisini değerlendirmeyi amaçladık ve ayrıca bu hastaların merkezimizde YANKO bulunmadığı sürede yoğun bakım ünitesinde yatış süresi ve sayılarını karşılaştırdık.

Yöntem: Bu gözlemsel, tek merkezli çalışmaya, Ekim 2017 ile Mart 2018 arasında YANKO tedavisi (F\&P Airvo 2TM optiflow cihazı ile 1-2 L/kg/dk.) uygulanan ağır akut bronşiolit tanılı hastalar (1-24 ay) dahil edildi. Hastane yatış süresi, YANKO tedavisinin 1., 6., 12. ve 24. saaatlerindeki solunum ve kalp hızı, kan basıncı ve oksijen saturasyonu değișimleri değerlendirildi.

Bulgular: Çalışmaya toplam 41 hasta dahil edildi, \% 66'sı ( $n=27)$ erkekti, ortalama yaş 7,5 55,6 ay ve orta-

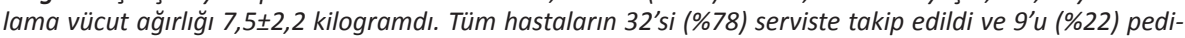
atrik yoğun bakım ünitesine devir edildi. Birinci, 6., 12. ve 24. saatlerde, kalp ve solunum hızı anlamlı azaldı, oksijen saturasyon değeri anlamlı arttı. Hastanede yatış süresinde, YANKO'nun olmadığı döneme göre anlamlı bir fark bulunmadı.

Sonuç: Çalışmamızda YANKO tedavisi kalp ve solunum hızını anlamlı azaltırken ve oksijen saturasyonunu anlamlı olarak arttırdı. YANKO tedavisinin etkinliği ile ilgili verilerimiz çok merkezli çalışmalarla değerlendirilmelidir.

Anahtar kelimeler: Akut bronşiolit, yüksek akımlı nazal kanül oksijen, respiratuar distres, pediarik yoğun bakım
Received/Geliş: 09.09.2019

Accepted/Kabul: 27.03.2020

Published Online/Online Yayın: 31.08.2020

Alkım Öden Akman Sağlık Bilimleri Üniversitesi, Ankara Çocuk Sağlığı ve Hastalıkları Hematoloji Onkoloji Eğitim ve Araştırma Hastanesi, Genel Pediatri Anabilim Dalı, Ankara - Turkey alkimakman@gmail.com ORCiD: 0000-0001-8080-7127

M. Koçoğlu 0000-0001-7623-6413

A. Güngör 0000-0003-4139-3480

C. Karagöl 0000-0002-2987-1980 Sağlık Bilimleri Üniversitesi, Ankara Çocuk Sağlığı ve Hastalıkları Hematoloji Onkoloji Eğitim ve Araştırma Hastanesi, Genel Pediatri Anabilim Dall, Ankara, Türkiye

B. Yalçın Burhan 0000-0002-5304-7588 Gazi Üniversitesi Tıp Fakültesi, Medikal Biyoloji ve Genetik ve Sağlık Bilimleri Üniversitesi, Ankara Çocuk Sağlığı ve Hastalıkları Hematoloji Onkoloji Eğitim ve Araştırma Hastanesi, Kalite birimi, Ankara, Türkiye 
M. Koçoğlu ve ark., Evaluation of the Effects of "High-Flow Nasal Cannula Oxygenation" Therapy on Vital Signs in Infants Diagnosed as Severe Acute Bronchiolitis Who Are Unresponsive to Conventional Therapy

\section{INTRODUCTION}

Acute bronchiolitis is an acute disease of the lower respiratory tract, which is especially seen in children under 2 years old, mostly caused by viral agents, characterized by tachypnea, retractions in the chest and wheezing and it progresses with inflammation of the bronchiole ${ }^{(1)}$. Acute bronchiolitis is the most common cause of presentations to hospital in children under one year old ${ }^{(2)}$. Although respiratory syncytial virus (RSV) is the most common cause of acute bronchiolitis, parainfluenza, human metapneumovirus, and rhinovirus are among the other agents. The diagnosis of acute bronchiolitis is clinically established. Laboratory findings and radiology may be guiding in support of the diagnosis and treatment planning ${ }^{(3,4)}$.

The most important approach in the treatment of acute bronchiolitis is rapid and effective initiation of the supportive therapy. For this purpose, hydration and oxygenation of the patient should be provided. Patients should be closely followed up for possible complications. Rapid elimination of hypoxia occurring in acute bronchiolitis restricts development of complications, morbidity, and mortality ${ }^{(4,5)}$.

In recent years, high-flow nasal cannula (HFNC) oxygen therapy has emerged as a promising therapeutic option for children with bronchiolitis. It provides humidified and heated air-oxygen mixture with high air flow delivered through a nasal cannula. High-flow nasal cannula oxygenation (HFNC) therapy, a noninvasive (NIV) method, is reported to more markedly improve blood oxygen saturation $\left(\mathrm{SpO}_{2}\right)$, respiratory rate (RR), heart rate (HR) and blood gas parameters, and to shorten rate of intubation in pediatric patients who developed respiratory distress/failure at follow up for acute bronchiolitis ${ }^{(6-8)}$. But the systematic review and meta-analysis suggested that HFNC is safe as an initial respiratory management for bronchiolitis but the evidence is still lacking.

The aim of this study was to determine whether HFNC therapy has significant effect on vital findings ( $\mathrm{RR}, \mathrm{HR}$, blood pressure and $\mathrm{SpO}_{2}$ ) in infants diagnosed with severe acute bronchiolitis and also, we compared the mean duration and the number of hospitalizations of these patients in the intensive care unit with the period where HFNC was not available in our center.

\section{MATERIAL and METHODS}

This observational, open-label, single center study included patients followed up in our service with the diagnosis of severe acute bronchiolitis at 1-24 months intervals, who did not give response to low flow oxygen and pharmacological therapy who had no chronic disease and were administered HFNC therapy between October 2017 and March 2018. The study was approved by the Local Ethics Committee of our hospital with a decision number of 2018-010.

Patients aged between 1 and 24 months diagnosed with severe acute bronchiolitis according to description criteria were included in the study ${ }^{(1,4,5)}$. Patients requiring invasive mechanical ventilation, cases with mental fog at admission, underlying chronic pulmonary or cardiac diseases, upper airway obstruction, and craniofacial malformation were excluded from the study. In order to determine whether HFNC therapy had significant effect, baseline $1^{\text {st }}, 6^{\text {th }}, 12^{\text {th }}$, and $24^{\text {th }}$ hour vital findings were recorded. Changes in these values at the specified time intervals were evaluated. We used the device F\&P Airvo 2TM optiflow in our study ${ }^{(9)}$.

High-flow nasal cannula oxygen therapy was terminated and the patients were transferred to the intensive care unit if:

1. Respiratory rate was not changed or increased compared to the baseline value or

2. Heart rate was not changed or increased compared to the baseline value or

3. Despite sufficient oxygen flow rate and $\mathrm{FiO}_{2}$ values were achieved during $\mathrm{HFNC}$ therapy, $\mathrm{SpO}_{2}$ value could not be raised above $94 \%{ }^{(10)}$.

Treatment of these patients was continued in the intensive care unit with "Nasal Continous Airway Pressure" (nCPAP) therapy and "Invasive Mechanical Ventilation" (IMV).

Patients' demographic data, frequency of treatment they have received (nebulized salbutamol, racemic epinephrine, ipratropium bromide, budesonide 
and intravenous hydration), and duration of hospitalization were determined. The rate of failure with HFNC and the rate of hospitalization in the intensive care unit were found. Effects of the introduction of HFNC therapy on the rate of hospitalization in the intensive care unit and total duration of hospitalization were compared with the period where this treatment method was not available in our hospital.

The data obtained were analyzed using IBM SPSS for Windows version 24.0 (IBM Corp., Armonk, NY) statistical software. Mean, standard deviation, frequency, median, and percentage values were calculated as descriptive statistics. Since the number of samples in groups was under 30, non-parametric tests were used in comparison of the groups. Chisquare test was used in analysis of categorical variables, Mann-Whitney $U$ test was used in comparison of two independent groups, Wilcoxon test in comparison of two dependent groups, Kruskal-Wallis test in comparison of more than two groups, and Friedman test in comparison of more than two dependent groups. $\mathrm{HO}$ hypothesis was rejected at $\mathrm{p}<0.05$ values.

\section{RESULTS}

Of total 41 patients included in the study, 66\% $(n=27)$ were boys. The mean age of the patients was found as $7.5 \pm 5.6$ months, and the mean body weight was $7.5 \pm 2.2 \mathrm{~kg}$. The demographic data were shown in Table 1. Body weight was under 3 percentile in

Table 1. The demographic datas of the patients.

\begin{tabular}{llcc}
\hline & & Number (n) & Percent (\%) \\
\hline Gender & Female & 14 & 34.1 \\
& Male & 27 & 65.9 \\
National status & TR & 33 & 80.5 \\
& Refugee & 8 & 19.5 \\
Gestational age & Term & 32 & 78.0 \\
& Late premature & 9 & 22.0 \\
& First episode & 28 & \\
*Weight for age & Recurrent episode & 13 & \\
(percentile) & $<3 p$ & 1 & 2.4 \\
& $3-97 p$ & 39 & 95.1 \\
& $>97$ p & 1 & 2.4 \\
& Total & 41 & 100.0 \\
\hline
\end{tabular}

* Centers for Disease Control and Prevention based on data from the WHO Child Growth Standards. one patient and above 97 percentile in another one. All patients were administered salbutamol, the use of inhaled adrenaline and ipratropium was lower. Except one patient, all patients were given iv hydration (Table 2).

Of the patients, $78 \%(n=32)$ were followed up in the ward, and $22 \%(n=9)$ were transferred to the intensive care unit. Of these patients, $14.6 \%(n=6)$ received nCPAP, and $2.4 \%(n=1)$ was intubated and administered invasive ventilation (Figure 1 ).

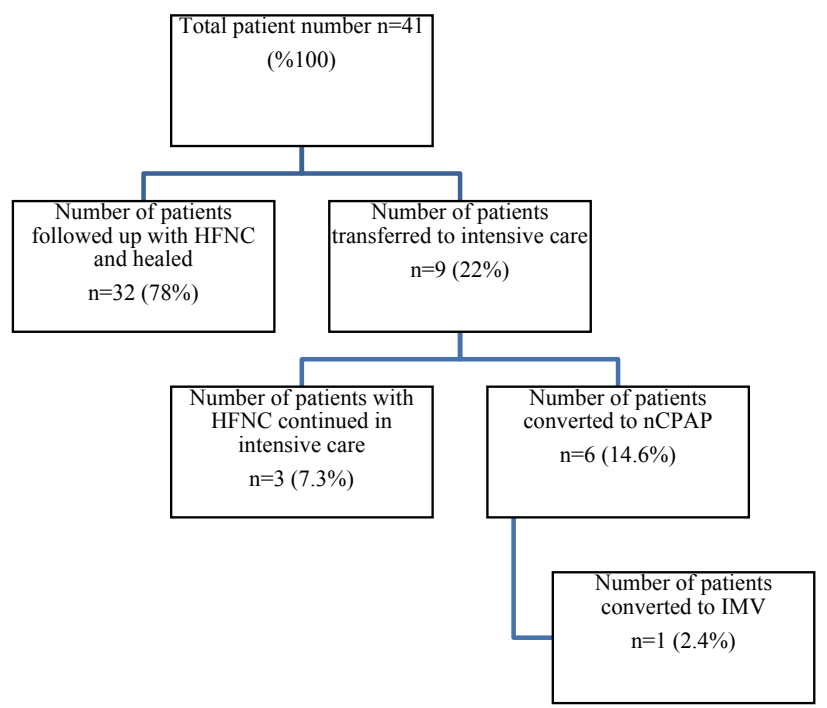

Figure 1. Patients' transfer to intensive care unit, nCPAP, and invasive ventilation status.

Table 2. The pharmacological treatments applied during hospitalization.

\begin{tabular}{lcc}
\hline Pharmacological treatments & Applied (n) & Unapplied (n) \\
\hline Nebulized Salbutamol & $41(100 \%)$ & 0 \\
Intravenous hidration & $40(97.6 \%)$ & $1(2.4 \%)$ \\
Nebulized epinephrine (1 mg of 1/1000) & $7(17.1 \%)$ & $34(82.9 \%)$ \\
Nebulized corticosteroid (budesonide) & $4(9.8 \%)$ & $37(90.2 \%)$ \\
Nebulized Ipratropium Bromide & $3(7.3 \%)$ & $38(92.7 \%)$ \\
\hline
\end{tabular}

The minimum duration of hospitalization was 5 days, and the maximum duration was 21 days (median: 9.3 days). Minimum duration of HFNC therapy administered in the patients was 2 hours, maximum 192 hours (median: 68 hours). The effect of HFNC therapy on vital findings in $24^{\text {th }}$-hour was: of 37 patients, respiratory rate was in normal range according to age in $56 \%(n=21), \mathrm{HR}$ in $51 \%(\mathrm{n}=19)$, and $\mathrm{SpO}_{2}$ in $62 \%(n=23)$ of the patients. HFNC did not fail within 
M. Koçoğlu ve ark., Evaluation of the Effects of "High-Flow Nasal Cannula Oxygenation" Therapy on Vital Signs in Infants Diagnosed as Severe Acute Bronchiolitis Who Are Unresponsive to Conventional Therapy

Table 3. Effect of HFNC on vital findings and rate of HFNC failure.

\begin{tabular}{|c|c|c|c|c|c|c|c|c|}
\hline & \multirow[b]{2}{*}{$\begin{array}{c}\text { Total } \\
\text { (n) }\end{array}$} & \multicolumn{2}{|c|}{$\mathrm{RR}^{*}$} & \multicolumn{2}{|c|}{$\mathrm{HR}^{*}$} & \multicolumn{2}{|c|}{$\mathrm{SpO}_{2}$} & \multirow[b]{2}{*}{$\begin{array}{l}\text { HFNC failure } \\
\text { (n) }\end{array}$} \\
\hline & & $\begin{array}{c}\text { Normal } \\
\text { (n) }\end{array}$ & $\begin{array}{l}\text { Abnormal } \\
\text { (n) }\end{array}$ & $\begin{array}{l}\text { Normal } \\
\text { (n) }\end{array}$ & $\begin{array}{l}\text { Abnormal } \\
\text { (n) }\end{array}$ & $\begin{array}{l}\text { Normal } \\
\text { (n) }\end{array}$ & $\begin{array}{c}\text { Abnormal } \\
\text { (n) }\end{array}$ & \\
\hline 0. hour & 41 & $2(4 \%)$ & 39 (96\%) & $4(8 \%)$ & 37 (92\%) & $10(24 \%)$ & 31 (76\%) & 0 \\
\hline 1. hour & 41 & $13(31 \%)$ & 28 (69\%) & $9(21 \%)$ & 32 (79\%) & 15 (57\%) & $26(43 \%)$ & 0 \\
\hline 6. hour & 41 & $10(24 \%)$ & 31 (76\%) & $17(41 \%)$ & 24 (59\%) & 27 (65\%) & 14 (35\%) & $3(7.3 \%)$ \\
\hline 12.hour & 38 & $16(42 \%)$ & 22 (58\%) & 21 (55\%) & 17 (45\%) & 26 (68\%) & 12 (32\%) & $1(2 \%)$ \\
\hline 24. hour & 37 & $21(56 \%)$ & 16 (44\%) & 19 (51\%) & 18 (49\%) & $23(62 \%)$ & 14 (38\%) & $1(2 \%)$ \\
\hline
\end{tabular}

*Data from: Fleming S. Thompson M. Stevens $R$. et al. Normal ranges of heart rate and respiratory rate in children from birth to 18 years of age: A systematic review of observational studies. Lancet 2011; 377:1011.

Table 4. Comparison of $\mathrm{SPO}_{2} \mathrm{HR}, \mathrm{RR}$ and Systolic BP of the study group at $0^{\text {th }} \mathbf{6}^{\text {th }} 12^{\text {th }}$ and $24^{\text {th }}$ hours.

\begin{tabular}{|c|c|c|c|c|c|c|}
\hline & 0. hour & 1. hour & 6. hour & 12. hour & 24. hour & $\mathbf{P}$ \\
\hline $\mathrm{SPO}_{2}$ & $\begin{array}{c}90^{\text {b.c.d.e }} \\
(86-93)\end{array}$ & $\begin{array}{c}92^{\text {a.c.d.ee }} \\
(89.5-96)\end{array}$ & $\begin{array}{c}94^{\text {a.b.o.dee }} \\
(89.5-97)\end{array}$ & $\begin{array}{c}96^{\text {a.b.c }} \\
(90.5-98)\end{array}$ & $\begin{array}{c}95^{\text {a.b.c. }} \\
(91-98)\end{array}$ & $<0.001$ \\
\hline $\mathrm{HR}$ (/min) & $\begin{array}{c}156^{\text {b.c.d.e }} \\
(148-156)\end{array}$ & $\begin{array}{c}142^{\text {a.c.d.ee }} \\
(127-142)\end{array}$ & $\begin{array}{c}129^{a . b} \\
(123-143)\end{array}$ & $\begin{array}{c}129^{a . b} \\
(112-144)\end{array}$ & $\begin{array}{c}129^{a . b} \\
(118-148)\end{array}$ & $<0.001$ \\
\hline (RR/min) & $\begin{array}{l}54^{\text {b.c.d.e }} \\
(50-60)\end{array}$ & $\begin{array}{l}48^{\text {a.d.e }} \\
(42-53)\end{array}$ & $\begin{array}{c}48^{\text {a.d.e }} \\
(43-52)\end{array}$ & $\begin{array}{c}46^{\text {a.b.c.ee }} \\
(44-50)\end{array}$ & $\begin{array}{l}44^{\text {a.b.c.c.d }} \\
(42-48)\end{array}$ & $<0.001$ \\
\hline Systolic blood pressure & $103(90-110)$ & $93(90-97)$ & $99(90-105)$ & $100(90-105)$ & $98(90-106)$ & $p=0.27$ \\
\hline
\end{tabular}

Data were expressed as median ( $25^{\text {th }}$ percentile $-75^{\text {th }}$ percentile). Friedman test was used in the comparison of more than two dependent groups. Wilcoxon test was used in comparison of two dependent groups. Post-hoc Bonferroni correction was made and $p<0.05$ values were considered statistically significant.

${ }^{a}$ shows the value different from $0^{\text {th }}$ hour

${ }^{b}$ shows the value different from $1^{\text {st }}$ hour

${ }^{c}$ shows the value different from $6^{\text {th }}$ hour

${ }^{d}$ shows the value different from $12^{\text {th }}$ hour

e shows the value different from $24^{\text {th }}$ hour

the first hour. HFNC failed between the $1^{\text {st }}$ and $6^{\text {th }}$ hours in 3 , one patient between the $6^{\text {th }}$ and $12^{\text {th }}$ hours in one, between the $12^{\text {th }}$ and $24^{\text {th }}$ hours in one one and at the $30^{\text {th }}$ hour patient in one patient. The mean duration of HFNC was found as 11.5 hours in the patients with failed HFNC (Table 3). One patient developed subcutaneous emphysema due to HFNC, and no other complications were noted.

When $\mathrm{SpO}_{2}, \mathrm{HR}, \mathrm{RR}$ and systolic blood pressure values of the study group were compared with baseline, $\mathrm{HR}, \mathrm{RR}$ decreased, while $\mathrm{SpO}_{2}$ increased at $1^{\text {st }}$, $6^{\text {th }}, 12^{\text {th }}$ and $24^{\text {th }}$ hours with progression of the treatment. This change was statistically significant $(p<0.001)$. No significant changes were found in systolic blood ppressure value (Table 4).

In 2015/2016 period where HFNC was not available, 173 patients were hospitalized with the diagnosis of acute bronchiolitis, the mean duration of hospitali- zation was 7.1 \pm 7.4 days, and the number of hospitalizations in the intensive care unit was 24. In 2017/2018 period where HNFC was introduced in our hospital, 174 patients were hospitalized, the mean duration of hospitalization was $6.1 \pm 4$ days, and the number of hospitalizations in the intensive care unit was 13. When the data were compared, any statistically significant difference was not found in terms of the duration of hospitalization. The number of patients hospitalized in the intensive care unit was lower in the period where HFNC therapy was used.

\section{DISCUSSION}

In our study, it was found that HFNC treatment provided significant improvements in vital signs from the $1^{\text {st }}$ hour in acute bronchiolitis patients that did not respond to conventional treatment. We determi- 
ned that RR and HR were significantly decreased, while baseline $\mathrm{SpO}_{2}$ was significantly increased when compared to $1^{\text {st }}, 6^{\text {th }}, 12^{\text {th }}$ and $24^{\text {th }}$ hours of HFNC therapy. In a study by Milani et al. ${ }^{(11)}$ with infants aged 12 months and younger diagnosed with moderate and severe bronchiolitis, a more effective drop was found in RR and HR especially within the first 8 hours in patients administered HFNC therapy compared to the patients given low flow oxygen therapy with mask. In a study by Söğütlü et al. ${ }^{(12)}$, it was reported that the vital signs of 32 children with lower respiratory tract infection improved significantly after the first hour of HFNC therapy. In our study group, RR and $\mathrm{HR}$ were significantly decreased, and $\mathrm{SpO}_{2}$ level was significantly increased at the $1^{\text {st }}, 6^{\text {th }}, 12^{\text {th }}$, and $24^{\text {th }}$ hours compared to the baseline values. In a study by Heikkila et al. ${ }^{(13)}$, HFNC therapy was found to significantly decrease the need for oxygen support and HR, and RR from the $6^{\text {th }}$ hour.

Our patient's HFNC treatment was converted to nCPAP therapy after a mean therapy of 11.5 hours because of unimprovement in vital signs. Kelly et al. (14) mentioned in their study that HFNC therapy failed at $7-14^{\text {th }}$ hours, and alternative ventilation methods were started from these time points.

In our study, 32 (78.0\%) patients were followed up in the ward, and 9 (22\%) were transferred to the intensive care unit. In a study by Sokuri et al. ${ }^{(15)}$, the use of HFNC in pediatric wards was significantly successful in acute bronchiolitis, and HFNC therapy was found to be successful in follow up of the patients in the wards, prevention of the failure of low flow oxygen therapy, and avoiding expensive and invasive intensive care unit treatments. Metge et al. ${ }^{(16)}$ compared nCPAP and HFNC therapy and determined that $\mathrm{HR}, \mathrm{RR}, \mathrm{pH}, \mathrm{pCO}_{2^{\prime}}$ and $\mathrm{FiO}_{2}$ values were similar in both groups. In a study by Milesi et al. ${ }^{(17)}$, durations of ventilation and hospitalization in the intensive care unit were found to be similar both in HFNC and nCPAP groups. In a crosssectional study by Turnham et al. ${ }^{(18)}$ including 117 hospitals in England and Wales, it was found that nCPAP and HFNC were commonly used in noninvasive ventilation, and HFNC was used as the first choice with its ease of use. In a study by Milani et al. ${ }^{(11)}$ performed with patients aged 12 months and younger and diag- nosed with moderate and severe bronchiolitis, duration of oxygen therapy and hospitalization were lower in patients administered HFNC therapy compared to those given standard oxygen therapy. In our study majority of patients administered HFNC were followed up in the pediatric ward. HFNC is a more simple, portable device that can be easily used in pediatric wards. Because of the limited number of beds in pediatric intensive care units in the countries with intense children population, using HFNC therapy under supervision of specialists can be considered as an important alternative to other NIV methods performed with equipment more dificult to transport and generally used in intensive care services.

HFNC therapy can be used as a safe and effective method especially in centers without pediatric intensive care units both during waiting for transport and during transport to an advanced center. Schlapbach et al. ${ }^{(19)}$ determined significant decrease in the need for other NIV and IMV therapy, and incidence of lifethreatened complications like pneumothorax, cardiac arrest after introduction of HFNC therapy in patients transferred with HFNC.

In our study, $82 \%(35 / 41)$ of patients benefited from HFNC therapy. Nine of the patients (22\%) transferred to the intensive care unit; 3 of them continued with HFNC, 6 of them (14.6\%) received nCPAP and one of the patients IMV therapy. One patient developed subcutaneous emphysema as a complication. In a study by Wegner et al. ${ }^{(20)}$ with 109 patients, any complication or mortality was not reported. In the same study, $70 \%(n=77)$ of the patients gave response to HFNC therapy and healed, 9 of the remaining patients $(n=32,30 \%)$ were directly intubated and connected to invasive ventilation, and 23 were connected to an alternative NIV. In a study by Spence et al. ${ }^{(21)}$, the need for intubation due to failed HFNC was found between $8 \%$ and $19 \%$. In a study by Schibler et al. ${ }^{(22)}$ performed with infants given oxygen therapy with HFNC, $20 \%$ decrease in heart and respiratory rates observed after the treatment was shown to reduce probability of IMV. In a study by Wing et al. ${ }^{(23)}$ evaluating 3 cohort studies, the rate of intubation decreased in acute bronchiolitis after introduction of HFNC therapy compared to baseline. 
High-flow nasal cannula oxygenation therapy has a positive effect on the nutrition of the patient with respiratory distress. Oral feeding could be initiated earlier, more uninterruptedly in patients with acute bronchiolitis under HFNC therapy ${ }^{(24)}$. Also, HFNC can decrease level of concern in parents since it reduces the need for intensive care, and facilitates follow up in the service beside the mother. Therefore, HFNC can be considered as the first choice in oxygen therapy given in patients with severe acute bronchiolitis.

As limitations, our study was designed crosssectionally and conducted in a single center with relatively limited number of patients. In our study, HFNC therapy could not be compared with the other ventilation methods including NCPAP and IMV because of the insufficient number of patients. Comparison data of only changes in the vital signs of HFNC therapy in the first 24 hours of patients who were unresponsive to conventional treatment could be presented.

In conclusion; HFNC therapy significantly decreased $R R$ and $H R$, and significantly improved $\mathrm{SpO}_{2}$. HFNC can be considered as a NIV method in acute bronchiolitis, because it is a rapid-acting, easy to access and practicable method with low rate of complications. The cost of treatment methods is important in demonstrating their feasibility. HFNC itself is not much expensive, but the interconnect cables of the device make up the actual cost. It is important to present the cost-effectiveness of this therapy in future studies. Although it is a good alternative treatment method for developing countries such as ours with a large population of children, it is necessary to conduct studies comparing costeffectiveness of various oxygen therapies.

Ethics Committee Approval: Ankara Children's Health and Diseases Hematology Oncology Training and Research Hospital Clinical Research Ethics Committee approval was received (2018-010).

Conflict of Interest: On behalf of all authors, the corresponding author states that there is no conflict of interest.

Funding: None.

Informed Consent: The informed consent was obtained from the patient's parents.

\section{REFERENCES}

1. Kou M, Hwang V, Ramkellawan N. Bronchiolitis: From Practice Guideline to Clinical Practice. Emerg Med Clin North Am. 2018;36(2):275-86. https://doi.org/10.1016/j.emc.2017.12.006

2. Franklin D, Dalziel S, Schlapbach LJ, Babl FE, Oakley E, Craig SS, et al. Early high flow nasal cannula therapy in bronchiolitis, a prospective randomised control trial (protocol): A Paediatric Acute Respiratory Intervention Study (PARIS). BMC Pediatr. 2015;15(1):1-8.

https://doi.org/10.1186/s12887-015-0501-x

3. Midulla F, Scagnolari C, Bonci E, Pierangeli A, Antonelli G, De Angelis $D$, et al. Respiratory syncytial virus, human bocavirus and rhinovirus bronchiolitis in infants. Arch Dis Child. 2010;95(1):35-41.

https://doi.org/10.1136/adc.2008.153361

4. Ralston SL, Lieberthal AS, Meissner HC, Alverson BK, Baley $\mathrm{JE}$, Gadomski AM, et al. Clinical practice guideline: the diagnosis, management, and prevention of bronchiolitis. Pediatrics. 2014;134(5):e1474-502.

https://doi.org/10.1542/peds.2014-2742

5. Lin J, Zhang Y, Xiong L, Liu S, Gong C, Dai J. High-flow nasal cannula therapy for children with bronchiolitis: a systematic review and meta-analysis. Arch Dis Child. 2019;0:1-13.

6. Petrarca L, Jacinto T, Nenna R. The treatment of acute bronchiolitis: past, present and future. Breathe. 2017;13:e24-6. https://doi.org/10.1183/20734735.000717

7. Sztrymf B, Messika J, Bertrand F, et al. Beneficial effects of humidified high flow nasal oxygen in critical care patients: a prospective pilot study. Intensive Care Med. 2011;37:178086. https://doi.org/10.1007/s00134-011-2354-6

8. Liu G, Fan C, Wu H. High-flow nasal cannula therapies for respiratory management in pediatric patients. Minerva Pediatr. 2018;70(5):488-92.

https://doi.org/10.23736/S0026-4946.17.04781-8

9. Fisher \& Paykel Healthcare. The Humidified High Flow Nasal Cannula Oxygen Guideline for Metropolitan Paediatric Wards and ED's, $1^{\text {st }}$ edition. 2016;13-22.

10. Ergul AB, Cal E, Samsa H, Gokcek I, Kaya A, Zararsiz GE. Using a high-flow nasal cannula provides superior results to OxyMask delivery in moderate to severe bronchiolitis: a randomized controlled study. Eur J Pediatr. 2018;177(8):12991307.

https://doi.org/10.1007/s00431-018-3191-1

11. Milani GP, Plebani AM, Arturi E, Brusa D, Esposito S, Era LD, et al. Using a high-flow nasal cannula provided superior results to low-flow oxygen delivery in moderate to severe bronchiolitis. . Acta Paediatr. 2016;1-5. https://doi.org/10.1111/apa.13444

12. Söğütlü $Y$, Biçer $S$, Kurt $G$, Şah $O$, Namdar $M$, Togaç $S$ ve ark. Alt Solunum Yolu Hastalığı Olan Çocuklarda Yüksek Akımlı Nazal Kanül Oksijenasyon Tedavisinin Yaşamsal Bulgular Üzerindeki Sonuçları. J Pediatr Emerg Intensive Care Med. 2016;3:121-30.

https://doi.org/10.4274/cayd.38358

13. Heikkilä $P$, Sokuri $P$, Mecklin $M$, Nuolivirta $K$, Tapiainen $T$, Peltoniemi $\mathrm{O}$, et al. Using high-flow nasal cannulas for infants with bronchiolitis admitted to paediatric wards is safe and feasible. Acta Paediatr. 2018; 0-3.

https://doi.org/10.1111/apa.14421

14. Kelly GS, Simon HK, Sturm JJ. High-flow nasal cannula use in 
children with respiratory distress in the emergency department: predicting the need for subsequent intubation. Pediatr Emerg Care. 2013;29(8):888-92. https://doi.org/10.1097/PEC.0b013e31829e7f2f

15. Sokuri $P$, Heikkilä $P$, Korppi M. National high-flow nasal cannula and bronchiolitis survey highlights need for further research and evidence-based guidelines. Acta Paediatr Int J Paediatr 2017;106(12):1998-2003. https://doi.org/10.1111/apa.13964

16. Metge P, Grimaldi C, Hassid S, Thomachot L, Loundou A, Martin $C$, et al. Comparison of a high-flow humidified nasal cannula to nasal continuous positive airway pressure in children with acute bronchiolitis: experience in a pediatric intensive care unit. Eur J Pediatr. 2014;173(7):953-8. https://doi.org/10.1007/s00431-014-2275-9

17. Milési C, Essouri S, Pouyau R, Liet J-M, Afanetti M, Portefaix $A$, et al. High flow nasal cannula (HFNC) versus nasal continuous positive airway pressure (nCPAP) for the initial respiratory management of acute viral bronchiolitis in young infants: a multicenter randomized controlled trial. Intensive Care Med. 2017;43(2):209-16. https://doi.org/10.1007/s00134-016-4617-8

18. Turnham H, Agbeko RS, Furness J, Pappachan J, Sutcliffe AG, Ramnarayan P. Non-invasive respiratory support for infants with bronchiolitis: a national survey of practice. BMC Pediatr. 2017;17(1):20.

https://doi.org/10.1186/s12887-017-0785-0
19. Schlapbach LJ, Schaefer J, Brady AM, Mayfield S, Schibler A. High-flow nasal cannula (HFNC) support in interhospital transport of critically ill children. Intensive Care Med. 2014;40(4):592-9.

https://doi.org/10.1007/s00134-014-3226-7

20. Wegner AA, Cespedes PF, Godoy MLM, Erices PB, Urrutia LC, Venthur $\mathrm{CU}$, et al. High flow nasal cannula in infants: Experience in a critical patient unit. Rev Chil Pediatr. 2015;86(3):173-81.

https://doi.org/10.1016/j.rchipe.2015.06.003

21. Spence KL, Murphy D, Kilian C, McGonigle R, Kilani RA. Highflow nasal cannula as a device to provide continuous positive airway pressure in infants. J Perinatol. 2007;30;27:772. https://doi.org/10.1038/sj.jp.7211828

22. Mayfield S, Bogossian F, O'Malley L, Schibler A. High-flow nasal cannula oxygen therapy for infants with bronchiolitis: Pilot study. J Paediatr Child Health. 2014;50(5):373-8. https://doi.org/10.1111/jpc.12509

23. Wing R, James C, Maranda LS, Armsby CC. Use of high-flow nasal cannula support in the emergency department reduces the need for intubation in pediatric acute respiratory insufficiency. Pediatr Emerg Care. 2012;28(11):1117-23. https://doi.org/10.1097/PEC.0b013e31827122a9

24. Sochet AA, McGee JA, October TW. Oral Nutrition in Children With Bronchiolitis on High-Flow Nasal Cannula Is Well Tolerated. Hosp Pediatr. 2017;7(5):249-55. https://doi.org/10.1542/hpeds.2016-0131 